\title{
The Relationship between Mycoplasmas and Cancer: Is It Fact or Fiction ? Narrative Review and Update on the Situation
}

\author{
Elhem Yacoub $\mathbb{D}^{1},{ }^{1}$ Osama Mohammed Saed Abdul-Wahab, ${ }^{2}$ Mishari H. Al-Shyarba $\mathbb{D}^{3}$ \\ and Boutheina Ben Abdelmoumen Mardassi (iD) \\ ${ }^{1}$ Specialized Unit of Mycoplasmas, Laboratory of Molecular Microbiology, Vaccinology, and Biotechnology Development, \\ Institut Pasteur de Tunis, University of Tunis El-Manar, Tunis, Tunisia \\ ${ }^{2}$ Department of Microbiology, Molecular Diagnostics Laboratory, Manchester Royal Infirmary, \\ Manchester University NHS Foundation Trust, Manchester, UK \\ ${ }^{3}$ Department of Surgery, College of Medicine, King Khalid University, P.O. Box 641, Abha 61421, Saudi Arabia
}

Correspondence should be addressed to Boutheina Ben Abdelmoumen Mardassi; bmardaa@yahoo.com

Received 17 March 2021; Accepted 15 July 2021; Published 31 July 2021

Academic Editor: Gagan Chhabra

Copyright (C) 2021 Elhem Yacoub et al. This is an open access article distributed under the Creative Commons Attribution License, which permits unrestricted use, distribution, and reproduction in any medium, provided the original work is properly cited.

\begin{abstract}
More than one million new cancer cases occur worldwide every year. Although many clinical trials are applied and recent diagnostic tools are employed, curing cancer disease is still a great challenge for mankind. Heredity and epigenetics are the main risk factors often related to cancer. Although, the infectious etiological role in carcinogenesis was also theorized. By establishing chronic infection and inflammation in their hosts, several microorganisms were suggested to cause cell transformation. Of these suspicious microorganisms, mycoplasmas were well regarded because of their intimate parasitism with host cells, as well as their silent and insidious role during infections. This assumption has opened many questions about the real role played by mycoplasmas in oncogenesis. Herein, we presented a sum up of many studies among the hundreds which had addressed the Mycoplasma-cancer topic over the past 50 years. Research studies in this field have first started by approving the mycoplasmas malignancy potential. Indeed, using animal models and in vitro experiments in various cell lines from human and other mammalians, many mycoplasmas were proven to cause varied modifications leading to cell transformation. Moreover, many studies have looked upon the Mycoplasma-cancer subject from an epidemiological point of view. Diverse techniques were used to assess the mycoplasmas prevalence in patients with cancer from different countries. Not less than 10 Mycoplasma species were detected in the context of at least 15 cancer types affecting the brain, the breast, the lymphatic system, and different organs in the genitourinary, respiratory, gastrointestinal, and urinary tracts. Based on these revelations, one should concede that detection of mycoplasmas often linked to "wolf in sheep's clothing" is not a coincidence and might have a role in cancer. Thorough investigations are needed to better elucidate this role. This would have a substantial impact on the improvement of cancer diagnosis and its prevention.
\end{abstract}

\section{Introduction}

Cancer is a devastating disease presenting an immense burden to humanity. According to latest statistics of the International Agency for Research on Cancer affiliated to the World Health Organization, barely 18 million new cancer cases were globally recorded in 2018, of which approximately 10 million have led to death [1]. Many causes and risk factors have been pointed to promote carcinogenesis establishment and development. Among these factors, some infectious agents have been suspected. In fact, according to the
American Cancer Society, up to $20 \%$ of cancers worldwide have been related to infectious agents. The causal relationship between different types of cancer and many oncoviruses such as papillomavirus, hepatitis B virus, and Epstein-Barr virus and bacteria such as Streptococcus bovis, Salmonella typhi, Chlamydia pneumoniae, Bartonella, and Helicobacter pylori has previously been well documented [2-12]. One of the suspected prokaryotes in malignancy are mycoplasmas. As these atypical bacteria are notorious for their capacity to implement a low-grade chronic inflammatory condition during cell infection without 
compromising viability, they were thought to be ideal for promoting cancer transformation [13]. Actually, the oncogenic potential and role of mycoplasmas in cancer development have been started to be investigated since the 1950s. Mycoplasmas were first detected in leukemia patients, and later, many studies have reported their identification in variant solid cancers either directly by PCR amplification of specific DNA segments or indirectly by evaluation of their antibody status in patients. Throughout this review, we will attempt to highlight the Mycoplasma-cancer relationship. Twenty years from the first review describing this relationship [14] and ten years after the second [15], we are today recalling what has been performed in this regard along with the new findings.

\section{Strategy Research}

We have conducted this review by synthesizing the results of research studies that consider Mycoplasma as an infectious agent involved in cancer. This was done by summarizing the available data with regard to the impact of mycoplasmas on the morphology, properties, and signaling pathways in mammalian cells and listing the different cases of cancer in which Mycoplasma species have been identified.

This review has been elaborated on the basis of screening in PubMed/MEDLINE databases, all types of published articles (research articles, reviews, and case reports) which have approached the Mycoplasma-cancer topic. This synthetic study was further complemented and refined by scanning the reference lists of the selected articles. All the bibliographical sources included in this review were carefully consulted and approved by all the authors.

In addition to the introduction and the conclusion, the main body of this review was conceived in three sections. The first is devoted to a general and concise description of distinctive features of mycoplasmas that made them suspicious infectious agents in cancer. To prove their malignancy potential, we have drawn on 27 studies, the synthesis of which constituted the content of the second section. The third section includes the first seven studies published between 1965 and 1970, which reported the presence of mycoplasmas in cancer patients, and 27 more recent studies published between 1995 and 2020. These have provided epidemiological information on the identified mycoplasmas in many types of cancer in several countries.

\section{Mycoplasmas: Atypical Tiny Microorganisms Capable of Causing Serious Troubles}

Mycoplasmas are atypical bacteria widespread in nature as parasites of human, mammals, reptiles, fish, birds, arthropods, and plants [16]. Mycoplasmas were first thought to be viruses given their reduced genome, minute size, and the total lack of a cell wall around their cytoplasmic membrane. They are considered as the smallest self-replicating prokaryotes [17]. The extensive genome reduction, through a process of reductive evolution, has limited the mycoplasmas biosynthetic capacity and hampered their metabolic pathways $[18,19]$. As a result, mycoplasmas are rendered completely dependent on their hosts to acquire essential precursors such as nucleotides and amino acids to insure their survival [20-23]. Mycoplasmas have tropism for many types of eukaryotic cells, and most of them are extracellular. However, host cell invasion was reported for some $\mathrm{Myco-}$ plasma species such as Mycoplasma fermentans and Mycoplasma penetrans $[24,25]$.

Despite their genetic deficiency, mycoplasmas are able to cause diseases of significant economic impact, especially in livestock animals [26-29]. For human, mycoplasmas have been also associated to many serious pathologies such as respiratory troubles [30-33], urogenital issues [34-37], infertility [38-41], rheumatic diseases [42-44], and AIDS [45-49]. These diseases are usually caused by acute mycoplasma infections. However, some mycoplasmas are capable to chronically colonize human cells without obvious clinical symptoms. Being a cell wall-free prokaryote, mycoplasmas interact closely with mammalian cells in silence for long time. This mute and extended interaction could be at the origin of alteration of many biological characteristics of mammalian cells [50]. Therefore, a potential association between mycoplasmas and cellular malignancy was suggested. The investigation of this oncogenic potential has been started from the middle of the 1960s, when several studies reported the detection of some human Mycoplasma species or their antibodies in patients suffering from leukemia [51-57]. Although these studies did not provide causal evidence for the involvement of mycoplasmas in cancer, they represented an opportunity for further investigations.

\section{Malignancy Potential of Mycoplasmas: Evidence In Vitro and In Vivo}

After the first reports suggesting the existence of a relationship between mycoplasmas and cancer, many experiments have subsequently been carried out to determine whether these bacteria are really endowed with oncogenetic properties or they are fortuitly identified in patients diagnosed with cancer. Other studies have attempted to explore whether mycoplasmas are directly involved in the onset of cancer or rather in its progression. Many cellular and molecular mechanisms of malignancy transformation were proposed for mycoplasmas.

For example, Paton et al. have shown that following serial passages of human diploid WJ-38 stem cells from normal embryonic lung and their infection with Mycoplasma orale, the growth of these cells regresses with noticeable chromosomal aberrations. This is the first study reporting such chromosomal disorders associated with Mycoplasma infection in normal human cells [58]. Malignant transformation induced by mycoplasmas was also reported to occur in blood cells (PBMCs) [59] and in many other human cell lines from different organs such as leiomyosarcoma cell line SK-UT-1B in the uterus [60], adenocarcinoma A549 cells in the lung [61], $\mathrm{BPH}-1$ cells in the prostate [62], and neuronal cell line BEM17 [63]. Besides human cells, studies have also demonstrated that some Mycoplasma species are effective in mediating changes in other mammalian cells in mouse, monkey, 
and hamster. The time of inoculation and the passage level were shown to affect transformation of infected mammalian cells $[64,65]$. These findings were consolidated by another similar study fulfilled by Tsai et al., by exploring the impact of infection with $M$. fermentans and $M$. penetrans species on mouse embryo cells $\mathrm{C} 3 \mathrm{H}$. In this study, a Mycoplasma-mediated oncogenesis was proved to take place in progressive steps and not in an acute way. In reality, the phenotypic changes noticed become progressively more conspicuous with the persistence of the Mycoplasma infection [13]. These two Mycoplasma species were also shown, in another study, to infect the murine 32D hematopoietic cell line, which is known to undergo interleukin-3-dependent apoptosis. It was found that mycoplasmas infection altered the properties of the 32D cells, preventing their apoptotic capacity, and enabling them to grow autonomously, independently of interleukin-3 stimulation. This was evidenced by the formation of tumors after injection of transformed 32D cells into nude mice [50]. It has also been found that the properties of stem cells are affected and altered by Mycoplasma infection [66].

Some researchers have been rather interested in studying the impact of activation or inactivation of Mycoplasma infections on the expression of target genes in different cells. These targets included oncogenes, tumor suppressors, proinflammatory cytokines, and growth factors. Zhang et al. have reported that chronic infection with the two human Mycoplasma species $M$. fermentans and $M$. penetrans is associated with an overexpression of $\mathrm{H}$-ras and c-myc oncogenes in $\mathrm{C} 3 \mathrm{H}$ embryo cells, which involved malignant cell transformation in mouse [67]. Subsequently, other scientific teams from the same laboratory have examined and compared the expression profiles of many genes (38 cytokine genes and 1185 other genes involved in oncogenesis, apoptosis, cell growth, and cell cycle regulation) in different human and mouse cells, before and after infection with different urogenital mycoplasmas. They concluded that distinctive mycoplasmas may have different effects (sometimes opposite) on the expression of a given gene. These effects might progressively but significantly alter several biological properties of mammalian cells (obvious changes in cell morphology or growth rate) and thus lead to malignant transformation [68, 69]. Using different approaches, Liu and Shou have also demonstrated that Mycoplasma infection has several effects on mammalian cells. These include genome breakdown and dysregulation of the expression of certain genes involved in apoptosis and tumorigenesis [70]. Furthermore, the repercussion of mycoplasmas infection on major regulation mechanisms of programmed cell death was also investigated. Logunov et al. have monitored the effects of $M$. fermentans, M. arginini, M. hominis, and M. arthritidis on the p53 tumor suppressor and the nuclear factor kappaB $(\mathrm{NF}-\kappa \mathrm{B})$ pathways, both involved in the maintenance of the cell cycle stability. Experiments carried out in vitro on a panel of human and mice cell lines showed that Mycoplasma infection inhibited p53 activity and activated the NF- $\kappa$ B, which are specific traits of human tumor cells. Moreover, it has been found that the same Mycoplasma species mentioned above cooperates with some oncogenes in cell transformation. However, the involved Mycoplasma protein has not been identified [71]. This was not the case in other studies identifying a M. hyorhinis-specific protein, p37, which promotes the invasiveness of the pathogen into the human cells. This demonstrates its involvement in the malignancy process [72-74]. A significant association between this Mycoplasma species and tumorigenesis was once again proved in vitro and in vivo in another study [75]. This was further strengthened by two more recent research studies supporting the role of $M$. hyorhinis in malignant transformation of gastric cells. This is achieved either by the activation of the NLRP3 inflammasome, which mediates the maturation of proinflammatory cytokines [76] or by activating the $\beta$-catenin signaling pathway, which is crucial for tissue homeostasis [77]. Furthermore, another way for the implication of mycoplasmas in cancer promotion was proposed. Mycoplasmas were shown to disturb the anticancer process either by causing resistance to the anticancer drugs or by repression of the natural killer cells activity. In two studies realized by two teams from the University of Maryland in the USA, the Mycoplasma chaperone DnaK was shown to have oncogenetic properties that render it responsible for the potency decrease of some proteins associated with critical cellular pathways, leading to a decline in the efficiency of anticancer drugs [78, 79]. Likewise, a group of Russian and German scientists have reported that sensitivity of tumorous cells to anticancer decreases after $M y$ coplasma infection. The authors have precisely worked with $M$. hyorhinis species [80]. In a Singaporean-Taiwanese study that came out just since few months, Mycoplasma infection was used to give rise to an artificial chronic inflammation condition in order to understand the influence of macrophages on natural killer cells in a context of a cancer. Results have shown that cancerous tissues infected by mycoplasmas were protected by macrophages from the attack of natural killer. Mycoplasmas have served as an example to prove that infection-induced inflammation helps in the cancer progression through natural killer cell repression moderated by macrophages [81].

As reported above, both in vitro and in vivo experimental data provided evidence that some mycoplasmas are able to affect the accuracy of genomic transmission during cell division and to disturb the coordination between cell cycle checkpoints. Many cases of chromosomal abnormalities (loss and translocations), karyotypic changes, and morphological modifications have been associated to $M y$ coplasma infections. More details about the above selected experimental studies are given in Table 1 . As well, a schema assembling the different effects caused by Mycoplasma infections on cell lines leading to malignant transformation is presented in Figure 1.

\section{Cancer-Mycoplasmas Relationship from an Epidemiological Standpoint: Overview of the Reported Cases}

After the above listed studies, admitting the malignancy potential of mycoplasmas, several epidemiological 
TABLE 1: In vitro and in vivo studies indicating malignant potential of mycoplasmas.

\begin{tabular}{|c|c|c|c|c|c|}
\hline $\begin{array}{l}\text { Mycoplasma } \\
\text { species }\end{array}$ & Cell line & Observed effect & Country & Year & Reference \\
\hline M. orale & $\begin{array}{l}\text { Human diploid cell strain WJ-38 } \\
\text { from normal embryo lung }\end{array}$ & $\begin{array}{l}\text { (i) Fragmented chromosomes } \\
\text { (ii) High level of breaks and polyploidy }\end{array}$ & UK & 1965 & {$[58]$} \\
\hline $\begin{array}{l}\text { M. hominis } \\
\text { M. fermentans } \\
\text { M. orale } \\
\text { M. pneumoniae } \\
\text { M. salivarium }\end{array}$ & BHK2I line of hamster fibroblasts & (i) Cell growth with altered colonial morphology & UK & 1966 & {$[65]$} \\
\hline $\begin{array}{l}\text { Spiroplasma } \\
\text { pirum }\end{array}$ & $\begin{array}{l}\text { Mouse NIH 3T3 cells } \\
\text { Monkey kidney CV-1 cells }\end{array}$ & $\begin{array}{l}\text { (i) Morphological changes of cells } \\
\text { (ii) Growth on soft agar and tumors development } \\
\text { in athymic and BALB } / c \text { mice }\end{array}$ & USA & 1986 & {$[64]$} \\
\hline M. hyorhinis & Mouse FS9 sarcoma cells & $\begin{array}{l}\text { (i) Reduction of invasiveness of transformed cells, } \\
\text { approved by using specific monoclonal antibody } \\
\text { directed against } M \text {. hyorhinis-specific protein p37 }\end{array}$ & Switzerland & 1990 & {$[72]$} \\
\hline $\begin{array}{l}\text { M. fermentans } \\
\text { M. penetrans }\end{array}$ & Mouse embryo $\mathrm{C} 3 \mathrm{H}$ cells & $\begin{array}{l}\text { (i) Phenotypic changes of infected cells } \\
\text { (ii) Ability to form tumors in animals } \\
\text { (iii)High soft agar cloning efficiency }\end{array}$ & USA & 1995 & [13] \\
\hline $\begin{array}{l}\text { M. fermentans } \\
\text { M. penetrans }\end{array}$ & Mouse embryo $\mathrm{C} 3 \mathrm{H}$ cells & $\begin{array}{l}\text { (i) Multistage malignant transformation } \\
\text { (ii) Induction of H-ras and c-myc oncogenes } \\
\text { expression } \\
\text { (iii) Morphological changes and uncontrolled cell } \\
\text { growth }\end{array}$ & USA & 1997 & {$[67]$} \\
\hline $\begin{array}{l}\text { Acholeplasma } \\
\text { laidlawii } \\
\text { M. fermentans }\end{array}$ & $\begin{array}{l}\text { Human uterine leiomyosarcoma } \\
\text { cell line SK-UT-1B }\end{array}$ & $\begin{array}{l}\text { (i) Chromosomal aberrations } \\
\text { (ii) Karyotypic variability }\end{array}$ & Russia & 1998 & {$[60]$} \\
\hline $\begin{array}{l}\text { M. penetrans } \\
\text { M. salivarium }\end{array}$ & & $\begin{array}{l}\text { (i) Activation of NF-Kb transcriptiontranscrption } \\
\text { factor }\end{array}$ & & & \\
\hline $\begin{array}{l}\text { M. genitalium } \\
\text { M. pneumoniae } \\
\text { M. orale } \\
\text { M. pirum }\end{array}$ & Murine hematopoietic $32 \mathrm{D}$ cell line & $\begin{array}{l}\text { (ii) Continuous growth without interleukin } \\
\text { stimulation } \\
\text { (iii) Chromosomal changes and trisomy } 19\end{array}$ & USA & 1999 & {$[50]$} \\
\hline $\begin{array}{l}\text { M. fermentans } M \text {. } \\
\text { genitalium } \\
\text { M. hominis } \\
\text { M. penetrans }\end{array}$ & $\begin{array}{l}\text { Immortalized cervical and } \\
\text { prostatic epithelial cells }\end{array}$ & $\begin{array}{l}\text { (i) Alteration in expression of cytokine genes } \\
\text { (more profoundly in cervical epithelial cells) - } \\
\text { (ii) radually alterationaltereration of important } \\
\text { biological properties }\end{array}$ & USA & 2000 & [69] \\
\hline M. fermentans & $\begin{array}{l}\text { Human peripheral blood } \\
\text { mononuclear cells (PBMCs) from } \\
\text { healthy blood donors }\end{array}$ & $\begin{array}{l}\text { (i) Karyotype change } \\
\text { (ii) Chromosomal loss or gain and translocation }\end{array}$ & USA & 2004 & {$[59]$} \\
\hline M. fermentans & Mouse embryo C3H cells & $\begin{array}{l}\text { (i) Aberrant expression of many oncogenes and } \\
\text { tumor repressors at different infection stages } \\
\text { (i) Invasion of cancer cells }\end{array}$ & USA & 2006 & {$[68]$} \\
\hline M. hyorhinis & $\begin{array}{c}\text { Prostate cancer PC-3 and DU145 } \\
\text { cell lines }\end{array}$ & $\begin{array}{l}\text { (ii) Nuclear enlargement } \\
\text { (iii) Anaplastic cells } \\
\text { (iv) Increase of migratory potential } \\
\text { (v) Changes in growth rhythm } \\
\text { (vi) Changes in morphology and gene expression }\end{array}$ & USA & 2007 & {$[73]$} \\
\hline Mycoplasma spp. & $\begin{array}{l}\text { Different types of cell lines } \\
\text { (mesenchymal, epithelial, and } \\
\text { myeloid) } \\
\text { Immortalized human bronchial } \\
\text { epithelial BEAS-2B cells } \\
\text { Lung adenocarcinoma A549 cells }\end{array}$ & $\begin{array}{l}\text { (i) Cell transformation, proliferation, } \\
\text { differentiation, a and apoptosis }\end{array}$ & USA & 2008 & {$[61]$} \\
\hline $\begin{array}{l}\text { M. fermentans } \\
\text { M. arginini } \\
\text { M. hominis } \\
\text { M. arthritidis }\end{array}$ & $\begin{array}{l}\text { H1299, MCF-7, HCT116, BJ, } \\
\text { REF52, } 293 \text { cells }\end{array}$ & $\begin{array}{l}\text { (i) Activation of NF- } \kappa \mathrm{B} \\
\text { (ii) Inhibition of p53 pathway activity } \\
\text { (iii) } \mathrm{M} \text {. arginini showed the strongest effect } \\
\text { among the tested species } \\
\text { (iv) Cooperation with some oncogenes in cell } \\
\text { transformation }\end{array}$ & $\begin{array}{c}\text { Russia } \\
\text { USA }\end{array}$ & 2008 & {$[71]$} \\
\hline
\end{tabular}


TABle 1: Continued.

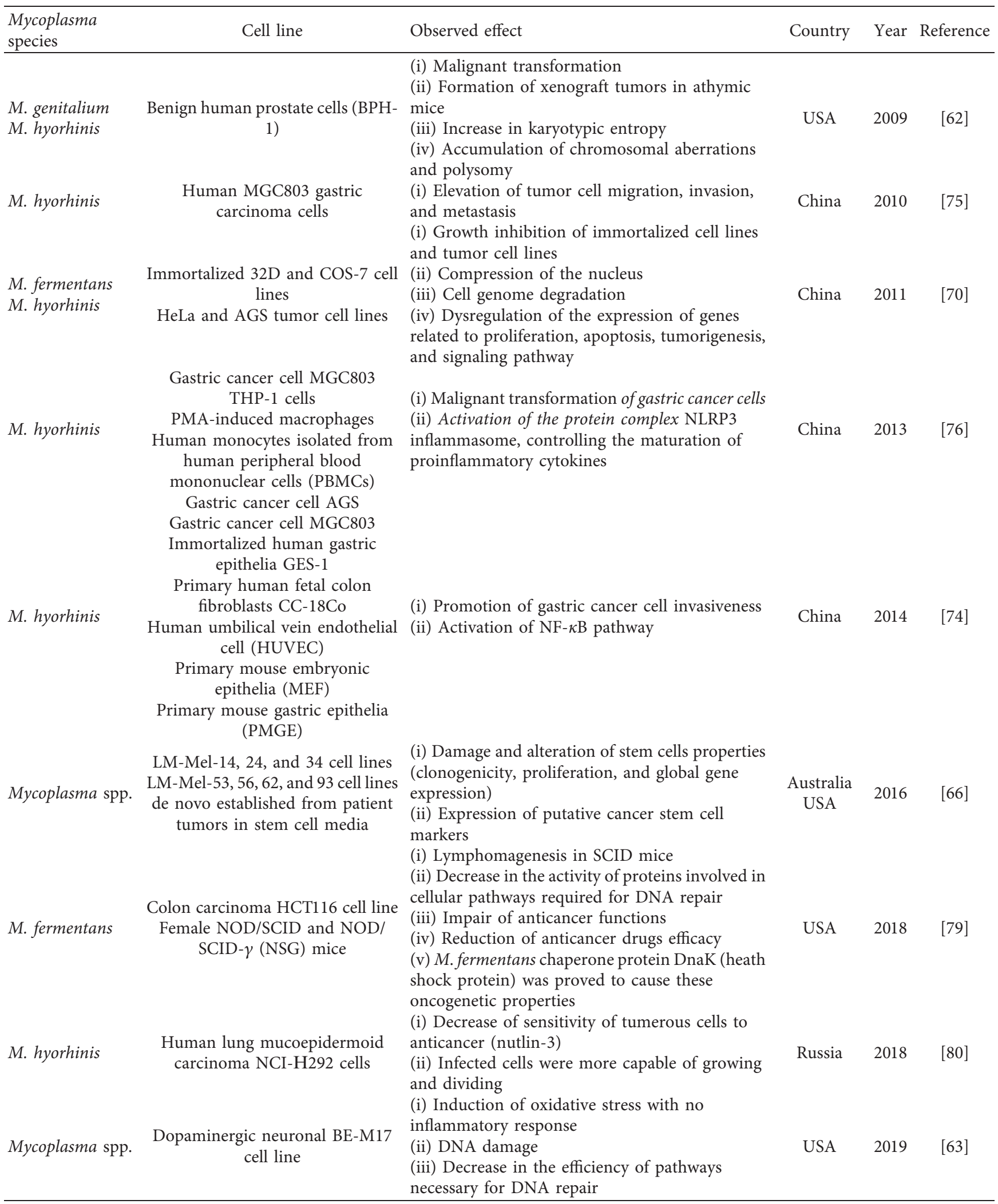


TABLE 1: Continued.

\begin{tabular}{|c|c|c|c|c|c|}
\hline $\begin{array}{l}\text { Mycoplasma } \\
\text { species }\end{array}$ & Cell line & Observed effect & Country & Year & Reference \\
\hline M. hyorhinis & $\begin{array}{l}\text { Human gastric cancer MGC803 } \\
\text { and BGC823 cell lines }\end{array}$ & $\begin{array}{l}\text { (i) Accumulation of nuclear signaling pathway } \\
\beta \text {-catenin } \\
\text { Enhancement of the expression of downstream } \\
\beta \text {-catenin genes } \\
\text { (ii) Induction of gastric cancer cell motility }\end{array}$ & China & 2019 & {$[77]$} \\
\hline M. fermentans & $\begin{array}{l}\text { HCT116 cells transfected with } \\
\text { expression vector containing } M \text {. } \\
\text { fermentans DnaK }\end{array}$ & $\begin{array}{l}\text { (i) DnaK protein plays a critical role in pathways } \\
\text { involved in recognition of DNA damage and } \\
\text { repair } \\
\text { (ii) Reduction of p53 stability and anticancer } \\
\text { functions }\end{array}$ & USA & 2020 & {$[78]$} \\
\hline Mycoplasma spp. & $\begin{array}{c}\text { Chronic myeloid leukemia (CML) } \\
\text { K562 and KCL-22 cell lines } \\
\text { Macrophages } \\
\text { Natural killer }\end{array}$ & $\begin{array}{l}\text { (i) Cancerous tissues infected by mycoplasmas } \\
\text { were protected by macrophages from the attack of } \\
\text { natural killer }\end{array}$ & $\begin{array}{l}\text { Singapore } \\
\text { Taiwan }\end{array}$ & 2020 & {$[81]$} \\
\hline
\end{tabular}

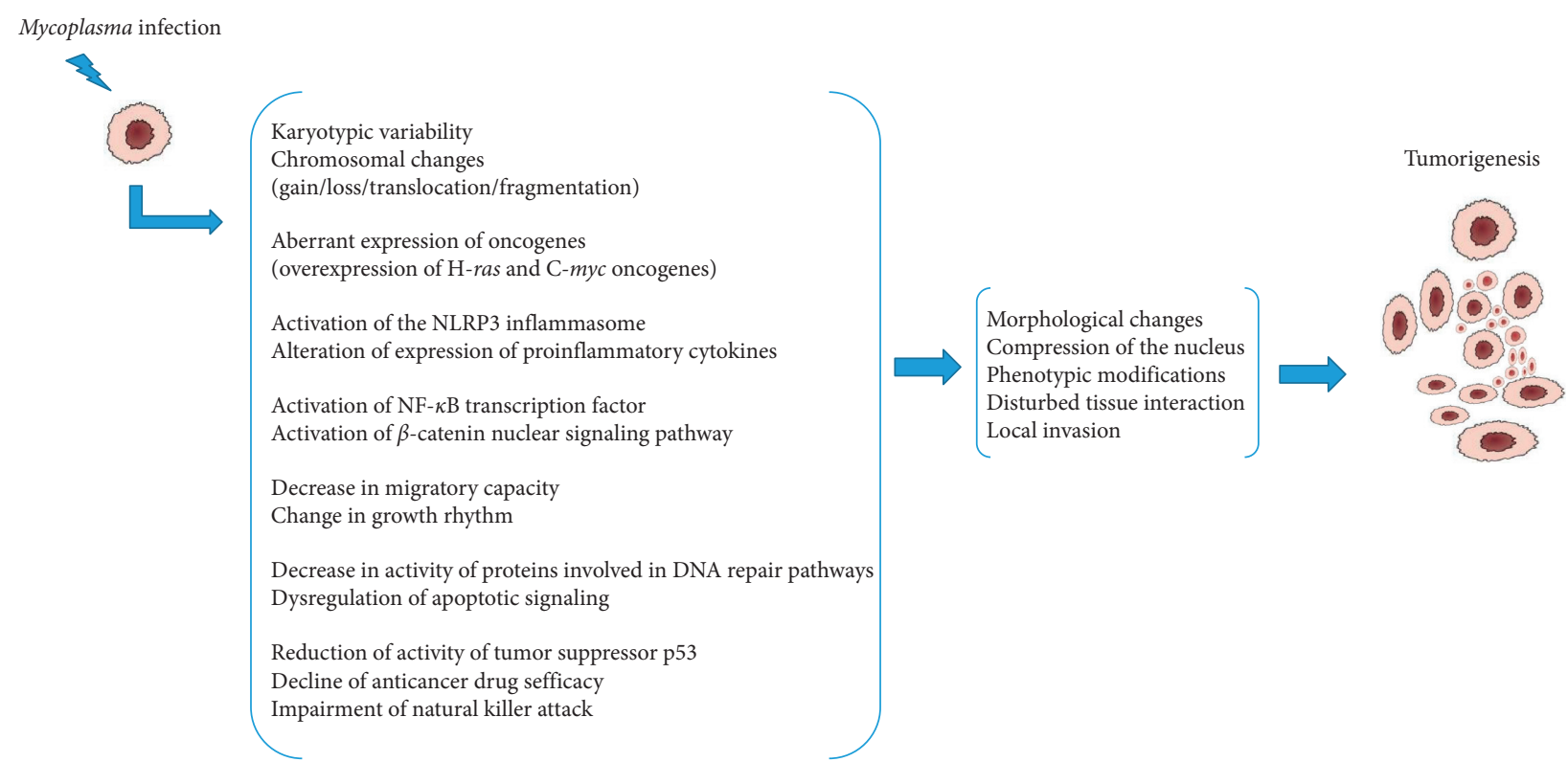

Figure 1: Modifications in Mycoplasma-infected cell lines leading to carcinogenesis.

investigations based on molecular and serological detection of these bacteria in different types of cancers have been documented in many countries around the world (Table 2).

5.1. Prostate Cancer. Prostate cancer is the second most commonly diagnosed cancer and the sixth cause of cancer death in men worldwide. Incrimination of urogenital mycoplasmas in this type of cancer has been evoked since the mid-twentieth century $[110,111]$. Based on this suggestion, some studies have been conducted later to experimentally prove the mycoplasmas potential in malignant transformation of prostate cells $[62,73]$. More recently (during the last 2010-2020 decade), this hypothesis was further sustained by several studies reporting the detection of mycoplasmas (by PCR or RT-PCR) or their antibodies (using ELISA technique) in patients suffering from prostate cancer. Different Mycoplasma species, notably $M$. hominis, $M$. genitalium, and Ureaplasma urealyticum, were identified with variable percentages in patients from different nationalities such as Russian, Turkish, Australian, Iranian, and Japanese [82-87]. In the same context, our team has recently shown the presence of $U$. parvum and $U$. urealyticum species in a cohort of Saudi patients diagnosed with prostate cancer with rates of $20 \%$ and $16 \%$, respectively [88].

It is important to notice that although the epidemiological data reported in these studies are interesting and persuasive, a luck of statistical and/or experimental evidences in some of them constitutes a limiting factor in the approving of the etiopathological role of mycoplasmas in prostate cancer.

5.2. Gastric Cancer. Malignant transformation in stomach cells is also one of the most frequently occurring cancers worldwide. In addition to the risk factors often mentioned in stomach cancer, such as smoking and lack of healthy nutrition, Helicobacter pylori infection was well established as a 
TABLE 2: Data from epidemiological studies performed in the context of Mycoplasma-cancer relationship.

\begin{tabular}{|c|c|c|c|c|c|c|c|}
\hline Cancer type & Method & Mycoplasma species & $\begin{array}{l}\text { Detection } \\
\text { rate }(\%)^{*}\end{array}$ & $\begin{array}{c}\text { Study } \\
\text { population* }\end{array}$ & Country & Year & Reference \\
\hline \multirow{14}{*}{ Prostate cancer } & RT-PCR & M. hominis & 15 & 125 & \multirow{2}{*}{ Russia } & \multirow{2}{*}{2011} & \multirow{2}{*}[82]{} \\
\hline & ELISA & M. hominis & 3 & 118 & & & \\
\hline & \multirow[t]{2}{*}{ PCR } & 7 Mycoplasma spp. & 35.4 & \multirow[t]{2}{*}{31} & \multirow[t]{2}{*}{ Turkey } & \multirow[t]{2}{*}{2013} & \multirow[t]{2}{*}{ [83] } \\
\hline & & M. genitalium & 9.56 & & & & \\
\hline & \multirow{2}{*}{ RT-PCR } & U. urealyticum & 0.86 & \multirow{2}{*}{115} & \multirow{2}{*}{ Australia } & \multirow{2}{*}{2014} & \multirow{2}{*}[84]{} \\
\hline & & U. parvum & 0 & & & & \\
\hline & \multirow{3}{*}{ PCR } & U. urealyticum & 1.61 & \multirow{3}{*}{62} & \multirow{3}{*}{ Iran } & \multirow{3}{*}{2015} & \multirow{3}{*}[85]{} \\
\hline & & M. genitalium & 0 & & & & \\
\hline & & M. genitalium & 40 & & & & \\
\hline & \multirow[t]{2}{*}{ PCR } & M. hyorhinis & 0 & \multirow[t]{2}{*}{45} & Japan & 2019 & {$[86]$} \\
\hline & & U. urealyticum & 0 & & & & \\
\hline & RT-PCR & M. hominis & 13.11 & 61 & Iran & 2020 & [87] \\
\hline & PCR and sequencing & U. parvum & 20 & & & & \\
\hline & & U. urealyticum & 16 & 50 & KSA & 2020 & [88] \\
\hline & PCR & 12 Mycoplasma spp. & 48 & 23 & Japan & 1995 & [89] \\
\hline & Southern blot & M. hyorhinis & 15 & 27 & Japan & 1990 & [89] \\
\hline & $\begin{array}{c}\text { Immunohistochemistry } \\
\text { PCR }\end{array}$ & M. hyorhinis & 56 & 90 & China & 2001 & {$[90]$} \\
\hline & Immunohistochemistry & M. hyorhinis & 54.1 & 98 & China & 2002 & [91] \\
\hline & Immunohistochemistry & M. hyorhinis & 45.9 & & & & \\
\hline & mmunonistocnemistry & M. fermentans & - & & & & \\
\hline Gastric cancer & & M. hyorhinis & 63.9 & & & & \\
\hline & Nested PCK & M. fermentans & 31.14 & & & & \\
\hline & & M. hyorhinis & 8.19 & 61 & China & 2006 & {$[92]$} \\
\hline & & M. fermentans & 3.27 & & & & \\
\hline & Culture & M. hyorhinis $+M$. & & & & & \\
\hline & & $\begin{array}{l}\text { fermentans } \\
\text { coinfection }\end{array}$ & 1.63 & & & & \\
\hline & Combined PCR-ELISA & 15 Mycoplasma spp. & 59.3 & 27 & USA & 1996 & [93] \\
\hline & Combined PCR-ELISA & 15 Mycoplasma spp. & 13 & 29 & Korea & 1998 & {$[94]$} \\
\hline & Nested PCR & 12 Mycoplasma spp. & 13 & & & & \\
\hline Ovarian cancer & Sequencing & M. arginini & 5 & 46 & USA & 2001 & [95] \\
\hline & sequencing & M. salivarium & 1 & & & & \\
\hline & $\begin{array}{l}\text { Lipid-associated membrane } \\
\text { protein-enzyme immunoassay } \\
\text { (LAMP-EIA) }\end{array}$ & M. genitalium & 11.76 & 68 & Sweden & 2011 & {$[96]$} \\
\hline & Combined PCR-ELISA & 15 Mycoplasma spp. & 33.3 & 9 & USA & 1998 & {$[97]$} \\
\hline & Nested PCR & M. penetrans & 45.45 & 55 & China & 2007 & {$[98]$} \\
\hline Cervical cancer & & Ureaplasma spp. & 51.4 & & & & \\
\hline & Metagenomic sequencing & M. hominis & 34 & 134 & USA & 2020 & [99] \\
\hline & & M. genitalium & 2.3 & & & & \\
\hline Colon cancer & & & 55.1 & 58 & & & \\
\hline Esophagus & Immunohistochemistry & & 50.9 & 53 & & & \\
\hline $\begin{array}{l}\text { cancer } \\
\text { Breast cancer }\end{array}$ & PCR & Mycoplasma spp. & 39.7 & 63 & China & 2001 & {$[90]$} \\
\hline Brain cancer & & & 41 & 91 & & & \\
\hline $\begin{array}{l}\text { Non-Hodgkin's } \\
\text { lymphoma }\end{array}$ & PCR & M. fermentans & 10.9 & 265 & UK & 2001 & {$[100]$} \\
\hline Renal cancer & Nested PCR & 15 Mycoplasma spp. & 82 & 33 & Turkey & 2005 & [101] \\
\hline Kenal cancer & Nested PCR & Mycoplasma spp. & 81.8 & 95 & China & 2008 & {$[102]$} \\
\hline Bladder cancer & Culture and nested PCR & M. penetrans & 41.8 & 55 & China & 2009 & {$[103]$} \\
\hline $\begin{array}{l}\text { Laryngeal } \\
\text { cancer }\end{array}$ & Culture and PCR & M. salivarium & - & 1 case & USA & 2012 & {$[104]$} \\
\hline Tongue cancer & TaqMan PCR & M. salivarium & - & 1 case & Germany & 2014 & {$[105]$} \\
\hline $\begin{array}{l}\text { Oropharynx } \\
\text { cancer }\end{array}$ & PCR & M. hominis & - & 1 case & France & 2020 & [106] \\
\hline
\end{tabular}


TABLE 2: Continued.

\begin{tabular}{lccccccc}
\hline Cancer type & Method & Mycoplasma species & $\begin{array}{c}\text { Detection } \\
\text { rate (\%)* }\end{array}$ & $\begin{array}{c}\text { Study } \\
\text { population* }\end{array}$ & Country & Year Reference \\
\hline \multirow{4}{*}{ Lung cancer } & Immunohistochemistry & Mycoplasma spp. & 52.6 & 59 & China & 2001 & {$[107]$} \\
& PCR & Mycoplasma spp. & 22.2 & 27 & Turkey & 2004 & {$[108]$} \\
& PLR & M.pneumoniae & - & 1 case & Canada & 2017 & {$[109]$} \\
\hline
\end{tabular}

${ }^{*}$ Detection rate in control populations is not reported here. Only patients with confirmed cancer diagnosis are considered. ( -$)$ sign, data not mentioned.

cause of this cancer. Indeed, it is the most and best studied case illustrating the direct involvement of an infectious agent in cancer [10-12]. This has encouraged further investigations to determine the potential involvement of other infectious agents in this type of cancer such as mycoplasmas. Results of studies aiming to seek for Mycoplasma species in patients with gastric cancer have shown the frequent detection of $M$. hyorhinis. This Mycoplasma species was identified by the Southern blot technique using specific Mycoplasma rDNA probes in 11 out 23 Japanese patients with gastric cancer (48\%) [89]. Higher detection rates around 56\% [90] and $54.1 \%$ [91] were reported in tumors from Chinese patients using the immunohistochemistry assay. A higher rate of $63.9 \%$ was obtained with nested PCR [92]. Interestingly, this last study also reported the detection of another Mycoplasma species, M. fermentans, however, always in conjunction with M. hyorhinis in the recruited patients. The authors of this study even succeeded in culturing these species on some cancerous specimens. This constitutes an irrefutable evidence of their existence in cancerous tissues.

5.3. Ovarian Cancer. According to the Global Cancer Observatory, nearly 300 thousand new cases of ovarian cancer were recorded in 2018. With about 185 thousand deaths, this type of cancer is considered one of the most deadly of the gynecological cancers [1]. Several risk factors contribute to the development of this type of cancer, the genetic predisposition being the most suspected $[107,112]$. However, the involvement of some urogenital microorganisms, such as Chlamydia trachomatis, in the etiology of ovarian cancer has also been raised. Such a suggestion has been investigated on the basis of the frequent detection of Chlamydia trachomatis, which is marked by a persistent infection in the female upper genital tract $[113,114]$. Endowed with the same properties, mycoplasmas were also suspected and their association with ovarian cancer was assessed in some studies. Indeed, in one of the investigations carried out, a combined PCR-ELISA method was designed for the detection of 15 Mycoplasma species in women with ovarian cancer. Mycoplasma infection was identified in more than half of 27 patients tested, which is a significant rate of about $60 \%$ [93]. Using the same combined procedure, Kim et al. found a rate of only $13.8 \%$ (4 among 29 Korean patients with ovarian cancer) that harbor Mycoplasma DNA [94]. Another study reported a rate of only $13 \%$ (6 samples out of a total of 46) of mycoplasmas in ovarian cancerous tissue using the nested PCR technique. Sequencing and BLAST analysis of the six positive cases identified $M$. salivarium and M. arginini. Given the low detection rate and the contaminating nature of the identified Mycoplasma species, the authors stated that their results are insufficiently consistent to confirm any relationship between Mycoplasma and ovarian cancer [95]. Idahl et al. undertook a similar work, but focused on searching for a particular species of $\mathrm{Myco-}$ plasma, M. genitalium. Their results revealed the presence of antibodies to M. genitalium in patients with ovarian cancer. But the statistics and comparison with controls showed that the association between this Mycoplasma species and ovarian cancer is not significant [96]. Overall, Mycoplasma detection rates in women with ovarian cancer do not seem to support the hypothesis that these microorganisms are involved in ovarian cancer. Larger epidemiological studies and more sophisticated methods are needed to better define the role of mycoplasmas in the tumorigenesis of ovarian tissue.

5.4. Cervical Cancer. Cervical cancer is one of the most common cancers among women worldwide, particularly in the low- and middle-income countries. Together with breast cancer, it is classified at the top of the most commonly diagnosed cancers and the leading causes of death in women [1]. Some carcinogenic microorganisms such as the human papillomavirus and the human immunodeficiency virus were identified as a cofactor for the development of cancerous lesions in the uterine cervix [115-117]. Because they are commonly detected in the cervical microbiome, mycoplasmas have brought the attention of some scientists who have eventually detected them in women with cervical cancer. Some Mycoplasma species were identified, notably, M. penetrans, $M$. genitalium, M. hominis, and U. urealyticum [97-99].

5.5. Other Types of Cancer (Colon, Esophagus, Breast, Brain, Lymphatic System, Kidney, Bladder, Larynx, Tongue, and Lung). In their study evaluating Mycoplasma infections in different types of cancer in humans, Huang et al. have communicated interesting results showing that Mycoplasma infection might occur in tumor cells in different organs such as the colon, esophagus, breast, and brain [90]. A tumor affecting the lymphatic system (non-Hodgkin's lymphoma) was also suspected to be related to Mycoplasma infection. Indeed, M. fermentans was incriminated [100]. The relationship between Mycoplasma infection and renal carcinoma has also been investigated. In two different studies, similar high detection rates, exceeding $80 \%$ of mycoplasmas DNA have been found in tissues of cancer patients. Such interesting results prompted the authors to consider the clinical significance of Mycoplasma infection in patients suffering from kidney cancer $[101,102]$. Likewise, the 
development of cancer in bladder cells was previously associated with mycoplasmas. M. penetrans was more involved in the development of bladder cell cancer [103].

Mycoplasmas have been detected in the oral cavity and in the upper and lower respiratory tracts. Baracaldo et al. reported the case of a man with cancer of the larynx, presenting empyema probably caused by $M$. salivarium. The suspicion of mycoplasmas occurred following the observation of the growth of small Gram-negative colonies in the pleural fluid collected from that patient. No other bacteria or fungi were detected in the sample. PCR followed by sequencing identified M. salivarium [104]. The same species was also detected in a tumor in a patient with squamous cell carcinoma of the tongue [105]. Another study reported the case of a young woman with a cervical squamous cell carcinoma probably related to oropharyngeal infection by $M$. hominis species [106]. Moreover, patients with lung cancer were also found to harbor mycoplasmas. Indeed, Huang et al. have communicated a relatively high detection rate about $52.6 \%$ for mycoplasmas in Chinese patients diagnosed with lung cancer [90]. Pehlivan et al. conducted the same research but found a Mycoplasma rate of $22.2 \%$ in patients with lung cancer [108]. In a more recent study presented during the CHEST annual meeting held in Canada in 2017, Reddy et al. reported the detection of M. pneumoniae IgM in the serum of an elderly woman diagnosed with adenocarcinoma of the lung [109].

\section{Conclusion}

Several studies have raised concern over Mycoplasma-cancer subject from different perspectives. The purpose of this article was to review the experimental and epidemiological studies on the possible association between cancer and mycoplasmas. Despite the multiple studies approving that mycoplasmas are endowed with a malignancy potential and those reporting data about their prevalence in patients with different types of cancer, the etiopathological role of mycoplasmas in tumorigenesis is still controversial and debatable. Indeed, the association between Mycoplasma and cancer has been often put in doubt as some studies did not report sufficient evidences on mycoplasmas' oncogenic properties [118] nor on their ability to induce transformation [119]. Aside of the repetitive detection of M. hyorhinis in gastric cancer, no other obvious specific association may be inferred between a given Mycoplasma species and a particular type of cancer. Nevertheless, the detection of mycoplasmas antibodies remains an efficient mean of monitoring their infection in patients with cancer and could provide evidence of their presence and therefore of their possible involvement. Although PCR amplification is the most useful and direct way to detect mycoplasma DNA, the in situ localization by culture remains the best one to confirm the presence of live and active mycoplasmas in tumor sites. This supports the hypothesis of causality for the involvement of these bacteria in host cells transformation.

We cannot ignore the vulnerability to infectious agents, including mycoplasmas, of an immunodeficient organism subsequent to cancer. To exclude such a case, further investigations should be undertaken to provide strong and irrefutable proof of a causal relationship between mycoplasmas and cancer and to elucidate the mechanisms governing their potential for malignancy. In order to do so, researchers should ask a question: could the cancers associated with infectious agents be avoided if the infection in cause is prevented? If it is shown that reliable diagnosis and early prevention of infection will prevent the development of cancer, this would strengthen the theory of the infectious origin of cancers.

\section{Data Availability}

The data used to support the findings of this study are included within the article.

\section{Conflicts of Interest}

The authors declare that they have no conflicts of interest.

\section{Authors' Contributions}

EY and BBAM conceived and designed the review and wrote the manuscript. EY conducted the database search and data collection. OMSAW and MHAlS drafted the article. All the bibliographical sources included in this review were carefully consulted and approved by all the authors. All authors approved the final version of the manuscript.

\section{Acknowledgments}

This review was supported by the Deanship of Scientific Research at King Khalid University (Abha city, Kingdom of Saudi Arabia) through General Research Project (G.R.P1/39/ 39).

\section{References}

[1] F. Bray, J. Ferlay, I. Soerjomataram, R. L. Siegel, L. A. Torre, and A. Jemal, "Global cancer statistics 2018: GLOBOCAN estimates of incidence and mortality worldwide for 36 cancers in 185 countries," CA: A Cancer Journal for Clinicians, vol. 68, no. 6, pp. 394-424, 2018.

[2] H. Zur Hausen, "Viruses in human cancers," Current Science, vol. 81, no. 5, pp. 523-527, 2001.

[3] D. M. Parkin, "The global health burden of infection-associated cancers in the year 2002," International Journal of Cancer, vol. 118, no. 12, pp. 3030-3044, 2006.

[4] R. Vogelmann and M. R. Amieva, "The role of bacterial pathogens in cancer," Current Opinion in Microbiology, vol. 10, no. 1, pp. 76-81, 2007.

[5] D. Mager, "Bacteria and cancer: cause, coincidence or cure? a review," Journal of Translational Medicine, vol. 4, no. 1, p. 14, 2006.

[6] S. Ellmerich, M. Scholler, B. Duranton et al., "Promotion of intestinal carcinogenesis by Streptococcus bovis," Carcinogenesis, vol. 21, no. 4, pp. 753-756, 2000.

[7] E. C. Lazcano-Ponce, J. F. Miquel, N. Munoz et al., "Epidemiology and molecular pathology of gallbladder cancer," CA: A Cancer Journal for Clinicians, vol. 51, no. 6, pp. 349-364, 2001. 
[8] A. J. Littman, L. A. Jackson, and T. L. Vaughan, "Chlamydia pneumoniae and lung cancer: epidemiologic evidence," Cancer Epidemiology Biomarkers and Prevention, vol. 14, no. 4, pp. 773-778, 2005.

[9] C. Dehio, "Bartonella-host-cell interactions and vascular tumour formation," Nature Reviews Microbiology, vol. 3, no. 8, pp. 621-631, 2005.

[10] H. Zur Hausen, "The search for infectious causes of human cancers: where and why," Virology, vol. 392, no. 1, pp. 1-10, 2009.

[11] E. Touati, "When bacteria become mutagenic and carcinogenic: lessons from H. pylori," Mutation Research/Genetic Toxicology and Environmental Mutagenesis, vol. 703, no. 1, pp. 66-70, 2010.

[12] B. J. Marshall and H. M. Windsor, "The relation of Helicobacter pylori to gastric adenocarcinoma and lymphoma: pathophysiology, epidemiology, screening, clinical presentation, treatment, and prevention," Medical Clinics of North America, vol. 89, no. 2, pp. 313-344, 2005.

[13] S. Tsai, D. J. Wear, J. W. Shih, and S. C. Lo, "Mycoplasmas and oncogenesis: persistent infection and multistage malignant transformation," Proceedings of the National Academy of Sciences, vol. 92, no. 22, pp. 10197-10201, 1995.

[14] N. Cimolai, "Do mycoplasmas cause human cancer?" Canadian Journal of Microbiology, vol. 47, no. 8, pp. 691-697, 2001.

[15] M. B. Rogers, "Mycoplasma and cancer: in search of the link," Oncotarget, vol. 2, no. 4, pp. 271-273, 2011.

[16] S. Razin, "The mycoplasmas," Microbiology Reviews, vol. 42, no. 2, pp. 414-470, 1968.

[17] S. Razin, D. Yogev, and Y. Naot, "Molecular biology and pathogenicity of mycoplasmas," Microbiology and Molecular Biology Reviews, vol. 62, no. 4, pp. 1094-1156, 1998.

[18] P. Sirand-Pugnet, C. Citti, A. Barre, and A. Blanchard, "Evolution of mollicutes: down a bumpy road with twists and turns," Research in Microbiology, vol. 158, no. 10, pp. 754-766, 2007.

[19] C. R. Woese, J. Maniloff, and L. B. Zablen, "Phylogenetic analysis of the mycoplasmas," Proceedings of the National Academy of Sciences, vol. 77, no. 1, pp. 494-498, 1980.

[20] E. Yacoub and B. Ben Abdelmoumen Mardassi, "Mm19, a mycoplasma meleagridis major surface nuclease that is related to the RE_AlwI superfamily of endonucleases," PLos One, vol. 11, no. 3, Article ID e0152171, 2016.

[21] L. Li, M. Krishnan, J. B. Baseman, and T. R. Kannan, "Molecular cloning, expression, and characterization of a $\mathrm{Ca}^{2+}$-dependent, membrane-associated nuclease of mycoplasma genitalium," Journal of Bacteriology, vol. 192, no. 19, pp. 4876-4884, 2010.

[22] C. C. Staats, J. Boldo, L. Broetto, M. Vainstein, and A. Schrank, "Comparative genome analysis of proteases, oligopeptide uptake and secretion systems in Mycoplasma spp," Genetics and Molecular Biology, vol. 30, no. 1, pp. 225-229, 2007.

[23] F. C. Minion, K. J. Jarvill-Taylor, D. E. Billings, and E. Tigges, "Membrane-associated nuclease activities in mycoplasmas," Journal of Bacteriology, vol. 175, no. 24, pp. 7842-7847, 1993.

[24] A. Yavlovich, A. Katzenell, M. Tarshis, A. A.-R. Higazi, and S. Rottem, "Mycoplasma fermentans binds to and invades HeLa cells: involvement of plasminogen and urokinase," Infection and Immunity, vol. 72, no. 9, pp. 5004-5011, 2004.

[25] S. C. Lo, M. M. Hayes, H. Kotani et al., "Adhesion onto and invasion into mammalian cells by Mycoplasma penetrans: a newly isolated mycoplasma from patients with AIDS,"
Modern Pathology: An Official Journal of the United States and Canadian Academy of Pathology, Inc, vol. 6, pp. 276-280, 1993.

[26] S. B. Dos Santos, R. P. B. De Melo, L. T. R. Da Silva et al., "Epidemiology of Mycoplasma agalactiae and Mycoplasma mycoides cluster in flocks of northeastern Brazil," Ciência Rural, vol. 48, no. 4, Article ID e20170427, 2018.

[27] N. Ferguson-Noel, "Mycoplasmosis," in Diseases of Poultry, D. E. Swayne, J. R. Glisson, L. R. McDougald, L. K. Nolan, D. L. Suarez, and V. Nair, Eds., Wiley, New Jersey, NY, USA, pp. 875-941, 2013.

[28] R. A. J. Nicholas, "Bovine mycoplasmosis: silent and deadly," Veterinary Record, vol. 168, no. 17, pp. 459-462, 2011.

[29] D. Maes, J. Segales, T. Meyns, M. Sibila, M. Pieters, and F. Haesebrouck, "Control of Mycoplasma hyopneumoniae infections in pigs," Veterinary Microbiology, vol. 126, no. 4, pp. 297-309, 2008.

[30] A. Yáñez, A. Martínez-Ramos, T. Calixto et al., "Animal model of Mycoplasma fermentans respiratory infection," BMC Research Notes, vol. 6, no. 1, p. 9, 2013.

[31] K. B. Waites and D. F. Talkington, "Mycoplasma pneumoniaeand its role as a human pathogen," Clinical Microbiology Reviews, vol. 17, no. 4, pp. 697-728, 2004.

[32] H. M. Foy, "Infections caused by Mycoplasma pneumoniae and possible carrier state in different populations of patients," Clinical Infectious Diseases, vol. 17, no. Suppl.1, pp. S37-S46, 1993.

[33] V. G. Loo, S. Richardson, and P. Quinn, "Isolation of Mycoplasma pneumoniae from pleural fluid," Diagnostic Microbiology and Infectious Disease, vol. 14, no. 5, pp. 443-445, 1991.

[34] S. Boujemaa, A. Ben Allaya, B. Mlik, H. Mardassi, and B. Ben Abdelmoumen Mardassi, "Phylogenetics of Mycoplasma hominis clinical strains associated with gynecological infections or infertility as disclosed by an expanded multilocus sequence typing scheme," Scientific Reports, vol. 8, no. 1, p. 14854, 2018.

[35] B. B. A. Mardassi, H. Ayari, A. Béjaoui-Khiari, B. Mlik, I. Moalla, and F. Amouna, "Genetic variability of the P120' surface protein gene of Mycoplasma hominis isolates recovered from Tunisian patients with uro-genital and infertility disorders," BMC Infectious Diseases, vol. 7, no. 1, p. 142, 2007.

[36] L. E. Manhart, C. W. Critchlow, K. K. Holmes et al., "Mucopurulent cervicitis and Mycoplasma genitalium," The Journal of Infectious Diseases, vol. 187, no. 4, pp. 650-657, 2003.

[37] C. R. Cohen, L. E. Manhart, E. A. Bukusi et al., "Association between Mycoplasma genitalium and acute endometritis," The Lancet, vol. 359, no. 9308, pp. 765-766, 2002.

[38] H. F. Clausen, J. Fedder, M. Drasbek et al., "Serological investigation of Mycoplasma genitalium in infertile women," Human Reproduction, vol. 16, no. 9, pp. 1866-1874, 2001.

[39] M. Upadhaya, B. Hibbard, and S. Walker, "The effect of ureaplasma urealyticum on semen characteristics," Fertility and Sterility, vol. 41, pp. 304-308, 1994.

[40] J. Fiberg, "Mycoplasmas and ureaplasmas in reproductive failure," Contemporary Obstetrics and Gynecology, vol. 28, pp. 271-286, 1983.

[41] D. M. Fowlkes, J. Macleod, and W. M. O’leary, “T-mycoplasmas and human infertility: correlation of infection with alterations in seminal Parameters $* *$ Supported by grants from the population council and from hoffmann-LaRoche, 
inc," Fertility and Sterility, vol. 26, no. 12, pp. 1212-1218, 1975.

[42] M. F. Barile, H. Yoshida, and H. Roth, "Rheumatoid arthritis: new findings on the failure to isolate or detect mycoplasmas by multiple cultivation or serologic procedures and a review of the literature," Clinical Infectious Diseases, vol. 13, no. 4, pp. 571-582, 1991.

[43] B. C. Cole and G. H. Cassell, "Mycoplasma infections as models of chronic joint inflammation," Arthritis and Rheumatism, vol. 22, no. 12, pp. 1375-1381, 1979.

[44] M. H. Williams, J. Brostoff, and I. M. Roitt, "Possible role of Mycoplasma fermentans in pathogenesis of rheumatoid arthritis," The Lancet, vol. 296, no. 7667, pp. 277-280, 1970.

[45] M. Gatski, D. H. Martin, K. Theall et al., "Mycoplasma genitalium infection among HIV-positive women: prevalence, risk factors and association with vaginal shedding," International Journal of STD and AIDS, vol. 22, no. 3, pp. 155-159, 2011.

[46] S.-C. Lo, R. Y.-H. Wang, T. Grandinetti et al., "Mycoplasma penetransinfections and seroconversion in patients with AIDS: identification of major mycoplasmal antigens targeted by host antibody response," FEMS Immunology and Medical Microbiology, vol. 44, no. 3, pp. 277-282, 2005.

[47] E. M. Shankar, N. Kumarasamy, P. Balakrishnan, S. Solomon, B. Devaleenol, and U. A. Rao, "Incidence of mycoplasma pneumoniae infection in HIV infected patients with underlying upper and lower respiratory complaints and correlation with various immunological and haematological findings," Retrovirology, vol. 2, no. Suppl 1, p. S97, 2005.

[48] R. Kovacic, V. Launay, P. Tuppin et al., "Search for the presence of six Mycoplasma species in peripheral blood mononuclear cells of subjects seropositive and seronegative for human immunodeficiency virus," Journal of Clinical Microbiology, vol. 34, no. 7, pp. 1808-1810, 1996.

[49] A. Blanchard and L. Montagnier, "AIDS-associated mycoplasmas," Annual Review of Microbiology, vol. 48, no. 1, pp. 687-712, 1994.

[50] S.-H. Feng, S. Tsai, J. Rodriguez, and S.-C. Lo, "Mycoplasmal infections prevent apoptosis and induce malignant transformation of interleukin-3-dependent 32D hematopoietic cells," Molecular and Cellular Biology, vol. 19, no. 12, pp. 7995-8002, 1999.

[51] W. H. Murphy, C. Bullis, L. Dabich, R. Heyn, and C. J. Zara fonetis, "Isolation of mycoplasma from leukemic and nonleukemic Patients2," JNCI: Journal of the National Cancer Institute, vol. 45, pp. 243-251, 1970.

[52] W. H. Murphy, I. J. Ertel, C. Bullis, and C. J. D. Zarafonetis, "Antibodies to Mycoplasma in sera of leukemic patients," Experimental Biology and Medicine, vol. 124, no. 2, pp. 366-372, 1967.

[53] M. F. Barile, "Mycoplasma and leukemia," Annals of the New York Academy of Sciences, vol. 143, no. 1, pp. 557-572, 1967.

[54] M. F. Barile, G. P. Bodey, J. Snyder, D. B. Riggs, and M. W. Grabowski, "Isolation of Mycoplasma orale from leukemic bone marrow and blood by direct culture," JNCI: Journal of the National Cancer Institute, vol. 36, pp. 155-159, 1966.

[55] L. Hayflick and H. Koprowski, "Direct agar isolation of Mycoplasmas from human leukaemic bone marrow," $\mathrm{Na}$ ture, vol. 205, no. 4972, pp. 713-714, 1965.

[56] J. T. Grace, J. S. Horoszewicz, T. B. Stim, E. A. Mirand, and C. James, "Mycoplasmas (PPLO) and human leukemia and lymphoma," Cancer, vol. 18, no. 10, pp. 1369-1376, 1965.
[57] R. J. Fallon, N. R. Grist, D. R. Inman, R. M. Lemcke, G. Negroni, and D. A. Woods, "Further sutdies of agents isolated from tissue cultures inoculated with human leukaemic bone-marrow," Bmj, vol. 2, no. 5458, pp. 388-391, 1965.

[58] G. R. Paton, J. P. Jacobs, and F. T. Perkins, "Chromosome changes in human Diploid-cell cultures infected with mycoplasma," Nature, vol. 207, no. 4992, pp. 43-45, 1965.

[59] S. Zhang, S. Tsai, T. T. Wu, B. Li, J. W.-K. Shih, and S.-C. Lo, "Mycoplasma fermentans infection promotes immortalization of human peripheral blood mononuclear cells in culture," Blood, vol. 104, no. 13, pp. 4252-4259, 2004.

[60] G. G. Polianskaia, T. N. Efremova, and N. A. Ender, "Effedct of mycoplasma contamination of the human uterine leiomyosarcoma cell line SK-UT-1B on karyotype structure," Tsitologiia, vol. 40, p. 23, 1998.

[61] S. Jiang, S. Zhang, J. Langenfeld, S.-C. Lo, and M. B. Rogers, "Mycoplasma infection transforms normal lung cells and induces bone morphogenetic protein 2 expression by posttranscriptional mechanisms," Journal of Cellular Biochemistry, vol. 104, no. 2, pp. 580-594, 2008.

[62] K. Namiki, S. Goodison, S. Porvasnik et al., "Persistent exposure to Mycoplasma induces malignant transformation of human prostate cells," PLoS One, vol. 4, no. 9, Article ID e6872, 2009.

[63] Y. Ji, M. Karbaschi, and M. S. Cooke, "Mycoplasma infection of cultured cells induces oxidative stress and attenuates cellular base excision repair activity," Mutation Research/ Genetic Toxicology and Environmental Mutagenesis, vol. 845, p. 403054, 2019.

[64] H. Kotani, D. Phillips, and G. J. Mcgarrity, "Malignant transformation of NIH-3T3 and CV-1 cells by a helical mycoplasma,Spiroplasma mirum, strain SMCA," In Vitro Cellular \& Developmental Biology, vol. 22, no. 12, pp. 756762, 1986.

[65] I. Macpherson and W. Russell, "Transformations in hamster cells mediated by mycoplasmas," Nature, vol. 210, no. 5043, pp. 1343-1345, 1966.

[66] C. Gedye, T. Cardwell, N. Dimopoulos et al., "Mycoplasma infection alters cancer stem cell properties in vitro," Stem Cell Reviews and Reports, vol. 12, no. 1, pp. 156-161, 2016.

[67] B. Zhang, J. W.-K. Shih, D. J. Wear, S. Tsai, and S.-C. Lo, "High-level expression of H-ras and c-myc oncogenes in mycoplasma-mediated malignant cell transformation," Experimental Biology and Medicine, vol. 214, no. 4, pp. 359-366, 1997.

[68] S. Zhang, S. Tsai, and S.-C. Lo, "Alteration of gene expression profiles during mycoplasma-induced malignant cell transformation," BMC Cancer, vol. 6, no. 1, p. 116, 2006.

[69] S. Zhang, D. J. Wear, and S.-C. Lo, "Mycoplasmal infections alter gene expression in cultured human prostatic and cervical epithelial cells," FEMS Immunology and Medical Microbiology, vol. 27, no. 1, pp. 43-50, 2000

[70] W. Liu and C. Shou, "Mycoplasma hyorhinis and Mycoplasma fermentans induce cell apoptosis and changes in gene expression profiles of 32D cells," Biological Research, vol. 44, no. 4, pp. 383-391, 2011.

[71] D. Y. Logunov, D. V. Scheblyakov, O. V. Zubkova et al., "Mycoplasma infection suppresses p53, activates NF- $\kappa$ B and cooperates with oncogenic Ras in rodent fibroblast transformation," Oncogene, vol. 27, no. 33, pp. 4521-4531, 2008.

[72] C. Schmidhauser, R. Dudler, T. Schmidt, and R. W. Parish, "A mycoplasmal protein influences tumour cell invasiveness 
and contact inhibition in vitro," Journal of Cell Science, vol. 95, no. 3, pp. 499-506, 1990.

[73] S. Goodison, K. Nakamura, K. A. Iczkowski, S. Anai, S. K. Boehlein, and C. J. Rosser, "Exogenous mycoplasmal p37 protein alters gene expression, growth and morphology of prostate cancer cells," Cytogenetic and Genome Research, vol. 118, no. 2-4, pp. 204-213, 2007.

[74] H. Duan, L. Chen, L. Qu et al., "Mycoplasma hyorhinis infection promotes NF- $\kappa \mathrm{B}$-Dependent migration of gastric cancer cells," Cancer Research, vol. 74, no. 20, pp. 5782-5794, 2014.

[75] H. Yang, L. Qu, H. Ma et al., "Mycoplasma hyorhinisinfection in gastric carcinoma and its effects on the malignant phenotypes of gastric cancer cells," BMC Gastroenterology, vol. 10, no. 1, p. 132, 2010.

[76] Y. Xu, H. Li, W. Chen et al., "Mycoplasma hyorhinis activates the NLRP3 inflammasome and promotes migration and invasion of gastric cancer cells," PLoS One, vol. 8, no. 11, Article ID e77955, 2013.

[77] X. Liu, Z. Rong, and C. Shou, "Mycoplasma hyorhinis infection promotes gastric cancer cell motility via $\beta$-catenin signaling," Cancer Medicine, vol. 8, no. 11, pp. 5301-5312, 2019.

[78] F. Benedetti, F. Cocchi, O. S. Latinovic et al., "Role of mycoplasma chaperone DnaK in cellular transformation," International Journal of Molecular Sciences, vol. 21, no. 4, p. 1311, 2020.

[79] D. Zella, S. Curreli, F. Benedetti et al., "Mycoplasma promotes malignant transformation in vivo, and its DnaK, a bacterial chaperone protein, has broad oncogenic properties," Proceedings of the National Academy of Sciences, vol. 115, no. 51, pp. E12005-E12014, 2018.

[80] U. A. Boyarskikh, A. S. Shadrina, M. A. Smetanina et al., "Mycoplasma hyorhinis reduces sensitivity of human lung carcinoma cells to Nutlin-3 and promotes their malignant phenotype," Journal of Cancer Research and Clinical Oncology, vol. 144, no. 7, pp. 1289-1300, 2018.

[81] Q. W. W. Choo, R. A. G. Koean, S. C. Chang et al., "Macrophages protect mycoplasma-infected chronic myeloid leukemia cells from natural killer cell killing," Immunology and Cell Biology, vol. 98, no. 2, pp. 138-151, 2020.

[82] Y. A. Barykova, D. Y. Logunov, M. M. Shmarov et al., "Association of Mycoplasma hominis infection with prostate cancer," Oncotarget, vol. 2, no. 4, pp. 289-297, 2011.

[83] S. M. Erturhan, O. Bayrak, S. Pehlivan et al., "Can mycoplasma contribute to formation of prostate cancer?" International Urology and Nephrology, vol. 45, no. 1, pp. 33-38, 2013.

[84] M. A. Yow, S. N. Tabrizi, G. Severi et al., "Detection of infectious organisms in archival prostate cancer tissues," BMC Cancer, vol. 14, no. 1, p. 579, 2014.

[85] G. Eslami, H. Goudarzi, N. Baseri et al., "The prevalence of ureaplasma urealyticum and mycoplasma genitalium in patients with prostate cancer in shohada hospital in Tehran, Iran," Novel Biomedicine, vol. 3, no. 2, pp. 73-78, 2015.

[86] M. Miyake, K. Ohnishi, S. Hori et al., "Mycoplasma genitalium infection and chronic inflammation in human prostate cancer: detection using prostatectomy and needle biopsy specimens," Cells, vol. 8, no. 3, p. 212, 2019.

[87] S. Saadat, P. Karami, M. Jafari et al., "The silent presence of mycoplasma hominis in patients with prostate cancer," Pathogens and Disease, vol. 78, no. 7, 2020.

[88] O. M. S. Abdul-Wahab, M. H. Al-Shyarba, B. B. A. Mardassi et al., "Molecular detection of urogenital mollicutes in patients with invasive malignant prostate tumor," Infectious Agents and Cancer, vol. 16, no. 1, p. 6, 2021.

[89] H. Sasaki, H. Igaki, T. Ishizuka, Y. Kogoma, T. Sugimura, and M. Terada, "Presence of Streptococcus DNA sequence in surgical specimens of gastric cancer," Japanese Journal of Cancer Research, vol. 86, no. 9, pp. 791-794, 1995.

[90] S. Huang, J. Li, J. Wu, L. Meng, and C. C. Shou, "Mycoplasma infections and different human carcinomas," World Journal of Gastroenterology, vol. 7, no. 2, pp. 266-269, 2001.

[91] J.-F. Ji, J. Zhang, C.-C. Shou, Y. Wang, and G.-W. Xu, "Mycoplasma hyorhinis in gastric cancer," Chinese Journal of Cancer Research, vol. 14, no. 2, pp. 84-87, 2002.

[92] C. Shou, "Mycoplasma hyorhinis exist in gastric carcinoma and promote cell malignancy," Proceedings of the American Association for Cancer Research, vol. 47, 2006.

[93] P. J. Chan, I. M. Seraj, T. H. Kalugdan, and A. King, "Prevalence of Mycoplasma conserved DNA in malignant ovarian cancer detected using sensitive PCR-ELISA," Gynecologic Oncology, vol. 63, no. 2, pp. 258-260, 1996.

[94] J. H. Kim, J. H. Na, M. H. Lee et al., "Presence of mycoplasma DNA in ovarian cancer tissue: detection by PCR-ELISA technique," Korean Journal of Gynecologic Oncology and Colposcopy, vol. 9, no. 1, pp. 70-78, 1998.

[95] J. T. Quirk, J. M. Kupinski, and R. A. DiCioccio, "Detection of mycoplasma ribosomal DNA sequences in ovarian tumors by nested PCR," Gynecologic Oncology, vol. 83, no. 3, pp. $560-562,2001$.

[96] A. Idahl, E. Lundin, M. Jurstrand et al., "Chlamydia trachomatis and Mycoplasma genitalium plasma antibodies in relation to epithelial ovarian tumors," Infectious Diseases in Obstetrics and Gynecology, vol. 2011, Article ID 824627, 10 pages, 2011.

[97] M. Kidder, P. J. Chan, I. M. Seraj, W. C. Patton, and A. King, "Assessment of archived paraffin-embedded cervical condyloma tissues for mycoplasma-conserved DNA using sensitive PCR-ELISA," Gynecologic Oncology, vol. 71, no. 2, pp. 254-257, 1998.

[98] Y.-Y. Zhu, L.-P. Zhou, Q. Zhang, Y. Hu, and Z.-X. Fang, "Isolation of Mycoplasma penetrans from blood and tissue specimens of patients with cervical cancer," China Journal of Zoonoses, vol. 23, p. 537, 2007.

[99] C. Klein, K. Samwel, C. Kahesa et al., "Mycoplasma Coinfection is associated with cervical cancer risk," Cancers, vol. 12, no. 5, p. 1093, 2020.

[100] J. G. Ainsworth, P. J. Easterbrook, J. Clarke, C. B. Gilroy, and D. Taylor-Robinson, "An association of disseminated Mycoplasma fermentans in HIV-1 positive patients with nonHodgkin's lymphoma," International Journal of STD and AIDS, vol. 12, no. 8, pp. 499-504, 2001.

[101] M. Pehlivan, S. Pehlivan, H. Onay, M. Koyuncuoglu, and Z. Kirkali, "Can Mycoplasma-mediated oncogenesis be responsible for formation of conventional renal cell carcinoma?" Urology, vol. 65, no. 2, pp. 411-414, 2005.

[102] C. Jun, L. Jianping, C. Wei, and C. Qi, "Clinical significance of detection of Mycoplasma DNA in renal cell carcinoma," Academic Journal of Xi'an Jiaotong University, vol. 6, p. 023, 2008.

[103] Y.-Y. Zhu, Z.-X. Yu, and L.-P. Zhou, "Detection of Mycoplasma penetrans in transitional cell carcinoma of bladder," Chin Journal of Zoonoses, vol. 25, pp. 238-240, 2009.

[104] R. Baracaldo, M. Foltzer, R. Patel, and P. Bourbeau, "Empyema caused by Mycoplasma salivarium," Journal of Clinical Microbiology, vol. 50, no. 5, pp. 1805-1806, 2012.

[105] B. Henrich, M. Rumming, A. Sczyrba et al., "Mycoplasma salivarium as a dominant coloniser of fanconi anaemia 
associated oral carcinoma," PLoS One, vol. 9, no. 3, Article ID e92297, 2014.

[106] S. Atallah, B. Bercot, V. Laurence, and C. Hoffmann, "Association of Mycoplasma Hominis and head and neck cancer with unknown primary," European Annals of Otorhinolaryngology, Head and Neck Diseases, vol. 137, no. 1, pp. 69-71, 2020.

[107] C. La Vecchia, "Epidemiology of ovarian cancer: a summary review," European Journal of Cancer Prevention, vol. 10, no. 2, pp. 125-129, 2001.

[108] M. Pehlivan, G. Itirli, H. Onay, H. Bulut, M. Koyuncuoglu, and S. Pehlivan, "Does Mycoplasma sp. play role in small cell lung cancer?” Lung Cancer, vol. 45, no. 1, pp. 129-130, 2004.

[109] M. Reddy, V. Arelli, and M. Kaushal, "Adenocarcinoma of lung presenting as mycoplasma pneumonia," Chest Journal, vol. 152, no. 4, p. 324A, 2017.

[110] M. Y. Heshmat, J. Kovi, J. Herson, G. W. Jones, and M. A. Jackson, "Epidemiologic association between gonorrhea and prostatic carcinoma," Urology, vol. 6, no. 4, pp. 457-460, 1975.

[111] R. Steele, R. E. M. Lees, A. S. Kraus, and R. Chandar, "Sexual factors in the epidemiology of cancer of the prostate," Journal of Chronic Diseases, vol. 24, no. 1, pp. 29-37, 1971.

[112] A. Berchuck, J. M. Schildkraut, J. R. Marks, and P. A. Futreal, "Managing hereditary ovarian cancer risk," Cancer, vol. 86, no. 11, pp. 2517-2524, 1999.

[113] R. B. Ness, M. T. Goodman, C. Shen, and R. C. Brunham, "Serologic evidence of past infection withChlamydia trachomatis, in relation to ovarian cancer," The Journal of Infectious Diseases, vol. 187, no. 7, pp. 1147-1152, 2003.

[114] J. Paavonen, "Chlamydia trachomatis and cancer," Sexually Transmitted Infections, vol. 77, no. 3, pp. 154-156, 2001.

[115] J. Masrour-Roudsari and S. Ebrahimpour, "Causal role of infectious agents in cancer: an overview," Caspian Journal of Internal Medicine, vol. 8, no. 3, pp. 153-158, 2017.

[116] E. A. Engels, R. J. Biggar, H. I. Hall et al., "Cancer risk in people infected with human immunodeficiency virus in the United States," International Journal of Cancer, vol. 123, no. 1, pp. 187-194, 2008.

[117] F. T. Cutts, S. Franceschi, S. Goldie et al., "Human papillomavirus and HPV vaccines: a review," Bulletin of the World Health Organization, vol. 85, no. 9, pp. 719-726, 2007.

[118] P. Ebbesen and K. Lind, "Lack of evidence for oncogenic or amyloid inducing qualities of Mycoplasma neurolyticum inoculated into BALB/c mice," Acta Pathologica, Microbiologica, et Immunologica Scandinavica, Pathology, Section $B$, vol. 76, pp. 594-600, 1969.

[119] B. Zhang, S. Tsai, J. W. K. Shih, D. J. Wear, and S.-C. Lo, "Absence of Mycoplasmal gene in malignant mammalian cells transformed by chronic persistent infection of Mycoplasmas," Experimental Biology and Medicine, vol. 218, no. 1, pp. 83-89, 1998. 